\title{
Community-based ecotourism: a new proposition for sustainable development and environmental conservation in Malaysia
}

\begin{abstract}
Community-based ecotourism is one of the most dynamic sectors of Malaysian tourism industry. The destination involved remote traditional communities where national parks, game reserves and other protected areas served as the background setting for such activities. Its principle is focused upon the benefits of tourism attained by local population and the environment while minimizing negative impacts. By empowering the locals with own governance and management partnerships within the area, community based ecotourism may reduce economic leakages, minimize negative impacts and concentrate the benefits locally. This study will discussed the key management issues of community-based tourism: government supports, sustainable use of local resources, participation of stakeholders, fair benefits sharing, strengthening of local institutions, linkages with regional and national levels and training. African and Asian experiences in these areas are highlighted.
\end{abstract}

Keyword: Legal community; Local institution; Economic benefit; Conversation of resources; Government support 